\title{
ANTIOXIDANT PROPERTIES OF DIFFERENT PORTIONS OF ORGANIC Anoectochilus formosanus HAYATA WITH DIFFERENT DRYING TREATMENTS
}

\author{
PROPRIEDADES ANTIOXIDANTES DE DIFERENTES PORÇÕES DE \\ ANOECTOCHILUS FORMOSANUS HAYATA ORGÂNICAS COM TRATAMENTOS \\ DE SECAGEM DIFERENTES
}

\author{
Shu-Hua CHIANG ${ }^{1}$; Chih-Chien LIN ${ }^{2}$ \\ 1. Department of Health and Creative Vegetarian Science, Fo Guang University, No. 160, Linwei Rd., \\ Jiaosi, Yilan County 26247, Taiwan; 2. Department of Cosmetic Science, Providence University, No. 200, Sec. 7, Taiwan Boulevard, \\ Shalu Dist., Taichung City 43301, Taiwan. chchlin@pu.edu.tw
}

\begin{abstract}
Anoectochilus formosanus HAYATA (Orchidaceae) is a valuable herb used as herbal medicine in Taiwan and other Asian countries. In order to enhance the economic efficiency of organic cultivation and understand how the processing affects plant properties, organic A. formosanus extracts were used as the investigative material in this study. The entire plant, the roots, stems and leaves from organic A. formosanus were freeze-dried or hot air-dried; all samples used methanol to extract. The antioxidant properties and active components were analyzed. The results indicated that antioxidant properties of both the freeze-dried and hot air-dried leaves of organic A. formosanus have better performance, including reducing power and $\alpha, \alpha$-diphenyl- $\beta$-picrylhydrazyl (DPPH) radical scavenging activity. The contents of phenols and flavonoids showed positive relationships with reducing power, DPPH radical scavenging activity and trolox equivalent antioxidant capacity. The contents of carotenoids positively correlated with trolox equivalent antioxidant capacity and the contents of all active components were negatively correlated with the ferrous ion chelating ability. To summarize the results, freeze-dried leaves of organic A. formosanus have better antioxidant properties at a suitable concentration. This study may raise the economic values of $A$. formosanus by the organic cultural technique.
\end{abstract} HAYATA

KEYWORDS: Antioxidant properties. Freeze-dried. Hot air-dried. Organic Anoectochilus formosanus

\section{INTRODUCTION}

Changes in the global market environment show that the aging population is increasing yearly. Most consumers agree that a particular food or drink intake can achieve the purpose of promoting health and disease prevention, thus resulting in the rise of the market of herbal health products used as complementary and alternative medicine (CAM)(CHAUHAN et al., 2013). Therefore, the development of new and functional herbal health products is a good way to promote people's health.

Reactive Oxygen Species (ROS) are the most abundant free radicals in cells, which are the unavoidable products during normal intracellular metabolism. However, a lot of cell components are believed to be damaged by ROS, including DNA damage, lipid peroxidation and also protein oxidation (CENCIONI et al., 2013; HAN; CHEN, 2013; CRUZ PADUA et al., 2014). There are two main antioxidant systems in cell (namely, enzymatic and non-enzymatic antioxidants), which perform systematically to scavenge the free radicals. Among them, vitamins (such as vitamin $\mathrm{C}$ and $\mathrm{E}$ ) are the most well-known non-enzymatic antioxidants. In addition to vitamins, various functional small molecules also act as the non-enzymatic antioxidants (CZEIZEL et al., 2013; PENG et al., 2014). For example, phenolics, flavonoids and carotenoids are naturally produced in plants with similar structural basics. These antioxidants can be acquired from the daily diets, belonging to a group of food-derived phytochemicals named as nutraceuticals (PETCHETTI et al., 2007).

The genus Anoectochilus (Orchidaceae) is a perennial herb found in many countries including Taiwan, China, India and other Asian countries (ZHANG et al., 2013). Among them, four species are found in Taiwan, including Anoectochilus formosanus HAYATA, Anoectochilus koshunensis HAYATA, Anoectochilus inabai, and Anoectochilus lanceolatus (TSENG et al., 2006). A. formosanus is a valuable herb used as herbal tea in Taiwan and China. It is also known as "King Medicine" due to the various biological effects, such as its antioxidant, anti-inflammation, hepato-protective, anticancer and immunomodulatory activities (LIN et al., 1993; WANG et al., 2002; TSENG et al., 2006; LAI et al., 2015). Therefore, A. formosanus is a potential phytomedicine that can be used to develop 
the herbal health products. However, to the best of our knowledge, no study has discussed the relationships between the different drying treatments and the antioxidant activities of different parts of A. formosanus.

The cultivation environment is very important for the mass ratio in different parts of $A$. formosanus; for the plant, illumination, temperature, humidity and fertilizing has significant relatedness. Besides, the preparation processes may also influence the characterization of plant extract. Therefore, in order to enhance the cultivation of the economic efficiency and understand how the processing affects plant properties, the organic, $A$. formosanus was used as study material. The entire plant, the roots, the stems, and the leaves, from organic A. formosanus were freeze-dried or hot airdried; all samples used methanol as extraction solvent. The antioxidant properties, including reducing power, ferrous ion chelating ability, $\alpha, \alpha-$ diphenyl- $\beta$-picrylhydrazyl (DPPH) radical scavenging activity, and trolox equivalent antioxidant capacity were analyzed. The active components measurement items included phenols, flavonoids, ascorbic acid, and carotenoids. The correlation of active components and antioxidant properties in the different parts of the plant were also analyzed in this presented study.

\section{MATERIAL AND METHODS}

\section{Materials}

The organic Anoectochilus formosanus HAYATA was provided by Winpower Biotech. Co., Ltd (Kaohsiung, Taiwan). Methanol (>95\%), butylated hydroxyanisole (BHA), $\alpha$-tocopherol, ascorbic acid, $\quad \alpha, \alpha$-diphenyl- $\beta$-picrylhydrazyl (DPPH), 6-hydroxy-2,5,7,8-tetramethylchroman-2carboxylic acid (Trolox), potassium ferricyanide, trichloroacetic acid, gallic acid, Folin-Ciocalteu reagent, potassium persulfate, 2,2'-azino-bis(3ethylbenzothiazoline-6-sulfonic acid) (ABTS), quercetin, metaphosphoric acid, 2,6dichloroindophenol (DCIP) and other chemicals were purchased from Sigma-Aldrich (St. Louis, MO, USA). Ethylenediaminetetraacetic acid (EDTA), ferrous chloride and ferrozine were purchased from Wako Pure Chemical Industries (Osaka, Japan). Deionized distilled water $\left(\mathrm{ddH}_{2} \mathrm{O}\right)$ for solutions and buffers was obtained from the Milli-Q system (Millipore, Bedford, MA, USA).

\section{Preparation of extracts}

The entire plant, the roots, the stems and the leaves from organic A. formosanus were freeze- dried $\left(-45^{\circ} \mathrm{C}\right)$ or hot air-dried $\left(55^{\circ} \mathrm{C}\right)$ overnight to remove water from the samples. In this study, methanol was used as the extraction solvent. Then $50 \mathrm{~mL}$ of methanol was added to $500 \mathrm{mg}$ of the dried organic A. formosanus, the ratios of sample weight to solvent volume are $1,2,4,6,8$ and 10 $\mathrm{mg} / \mathrm{mL}$; samples were then placed at a stirrer for 30 min. After the extraction procedure, the filtrates were collected and lyophilized.

\section{Reducing power}

Each $10 \mathrm{~mL}$ of the extracts with different concentrations and each antioxidants BHA and $\alpha$ tocopherol were individually mixed with $5 \mathrm{~mL}$ sodium phosphate buffer $(0.2 \mathrm{M}, \mathrm{pH} 6.6)$ and $1 \mathrm{~mL}$ $1 \%$ potassium ferricyanide, and then the mixture was incubated at $50^{\circ} \mathrm{C}$ for $20 \mathrm{~min}$. After trichloroacetic acid $(1 \mathrm{~mL}, 10 \%$, w/v) was added, the mixture was centrifuged at $4^{\circ} \mathrm{C}, 3000 \mathrm{rpm}$ for 10 min. The $5 \mathrm{~mL}$ supernatant was mixed with $5 \mathrm{~mL}$ $\mathrm{ddH}_{2} \mathrm{O}$ and $1 \mathrm{~mL}$ ferric chloride $(0.1 \%)$. After 10 $\min$ at $25^{\circ} \mathrm{C}$, the absorbance of mixture was determined at $700 \mathrm{~nm}\left(\mathrm{~A}_{700 \mathrm{~nm}}\right)$ (Oyaizu, 1986).

\section{Chelating effect on ferrous}

Each $5 \mathrm{~mL}$ of the extracts with different concentrations and EDTA were individually mixed with $3.7 \mathrm{~mL}$ sodium phosphate buffer $(0.05 \mathrm{M}, \mathrm{pH}$ 7.4), $0.1 \mathrm{~mL}$ ferrous chloride $(2 \mathrm{mM})$ and $0.2 \mathrm{~mL}$ ferrozine $(5 \mathrm{mM})$. After $10 \mathrm{~min}$ at $25^{\circ} \mathrm{C}$, the absorbance of the mixture was measured at $562 \mathrm{~nm}$. The lower absorbance indicates the higher chelating effect (DECKER E WELCH, 1990).

\section{Scavenging effect on 2,2-diphenyl-1- picrylhydrazyl (DPPH) radicals}

Each $5 \mathrm{~mL}$ of extracts with different concentrations and each antioxidants BHA and $\alpha$ tocopherol were individually mixed with $1 \mathrm{~mL}$ of methanolic solution containing DPPH radicals and the final concentration of DPPH was $1 \mathrm{mM}$. The mixture was shaken vigorously and left for $30 \mathrm{~min}$ at $25^{\circ} \mathrm{C}$ in the dark, and the absorbance was then determined at $517 \mathrm{~nm}$ (SHIMADA et al., 1992).

\section{Trolox equivalent antioxidant capacity (TEAC)}

The mixture of $7.0 \mathrm{mM}$ ABTS and $2.45 \mathrm{mM}$ potassium persulfate was used at room temperature in the dark to form the stable radical cation $\mathrm{ABTS}^{+}$. The solution was diluted with ethanol and absorbance was measured at $734 \mathrm{~nm}$. An aliquot of each sample was mixed with the solution of the radical cation $\mathrm{ABTS}^{+}(0.5 \mathrm{~mL})$ and the decrease of absorbance was measured at $734 \mathrm{~nm}$ after $6 \mathrm{~min}$. Different concentrations of trolox were used as 
positive reference. Therefore, higher TEAC level indicates higher antioxidant effect (ARNAO et al., 1996).

\section{Quantification of total phenolic compounds}

The samples and standard gallic acid solutions with $0.5 \mathrm{~mL}$ were diluted with $7 \mathrm{~mL}$ water. Subsequently, $0.5 \mathrm{~mL}$ Folin-Ciocalteu reagent was added and the solution was incubated at $100^{\circ} \mathrm{C}$ for $1 \mathrm{~min}$. The absorbance was measured at $750 \mathrm{~nm}$ and the results were calibrated using the well-known phenolic compound gallic acid and expressed as the equivalents of gallic acid in $\mathrm{mg} / \mathrm{g}$ (AINSWORTH E GILLESPIE, 2007).

\section{Quantification of flavonoids}

The samples and standard quercetin solutions with $1 \mathrm{~mL}$ were added to $1 \mathrm{~mL}$ of $2 \%$ methanolic $\mathrm{AlCl}_{3} \cdot 6 \mathrm{H}_{2} \mathrm{O}$. After 10 min incubation at room temperature, the absorbance was measured at $430 \mathrm{~nm}$. The results were expressed as the equivalents of quercetin in $\mathrm{mg} / \mathrm{g}$ (QUETTIERDELEU et al., 2000).

\section{Quantification of ascorbic acid}

The sample with $0.5 \mathrm{~g}$ was extracted by 50 $\mathrm{mL}$ of $1 \%$ metaphosphoric acid. Subsequently, 1 $\mathrm{mL}$ of extract solution was added to $9 \mathrm{~mL}$ DCIP (15 $\mathrm{mg} / \mathrm{L})$. The absorbance was measured within $15 \mathrm{~s}$ at $515 \mathrm{~nm}$. The level of ascorbic acid was quantified by the standard curve (KLEIN; PERRY, 1982).

\section{Quantification of carotenoids}

According to the standard method for carotenoids quantification from A.O.A.C., $2 \mathrm{~g}$ samples were individually extracted by $100 \mathrm{~mL}$ acetone/n-hexane (6:4) solution with $0.1 \mathrm{~g} \mathrm{MgCO}_{3}$ for $5 \mathrm{~min}$. The solutions were than extracted with $\mathrm{MgO}-$ Celite column and eluted by a $50 \mathrm{~mL}$ acetone/n-hexane (1:9) elution solution. The absorbance was measured at $430 \mathrm{~nm}$ and the level of carotenoids was quantified by the standard curve(HORWITZ E AOAC INTERNATIONAL., 1980).

The reducing power of the freeze-dried and the hot air-dried methanolic extracts of different portions from organic $A$. formosanus

To prepare the extracts, the entire plant, the roots, the stems and the leaves of organic $A$. formosanus were individually freeze-dried or hot air-dried to remove water from the samples; methanol was then used as the solvent to extract the active compounds from organic $A$. formosanus. The prepared extracts were subsequently used to analyse their antioxidant properties and active components.

\section{Statistical analysis}

Statistical analysis was performed using the variance (one-way ANOVA), Scheffe's method and the correlation analyses of Statistic Analysis System (SAS) to confirm the correlations between each sample and the antioxidant activity.

\section{RESULTS}

As shown in Figure 1, the reducing power of the freeze-dried and hot air-dried methanolic extracts of different portions from organic $A$. formosanus was examined. For freeze-dried extracts, the freeze-dried leaves extract has a better reducing power than the other parts from the concentrations of 1 to $10 \mathrm{mg} / \mathrm{mL}$ (Figure 1A). The extract of freeze-dried roots has a lower reducing power. Although the reducing powers of all tested freeze-dried extracts are relatively different when compared to those of the BHA and $\alpha$-tocopherol groups (control groups) at all tested concentrations, we found that all freeze-dried extracts have moderate reducing powers (Figure 1A). In contrast, in Figure 1B, hot air-dried extracts have similar pattern with freeze-dried extracts. The hot air-dried leaves extract has better reducing power than those of the other parts at all tested concentrations. However, both the extracts of freeze-dried roots and stems have the lowest reducing power. Moreover, $10 \mathrm{mg} / \mathrm{mL}$ hot air-dried leaves extract has the greatest reducing power (about $\mathrm{A}_{700}=1.5$ ) in all prepared extracts except in the control groups (Figure 1B). Besides, results in Figure 1 also indicated that both freeze-dried and hot air-dried leaves extracts have better reducing power than other extracts.

In the case of the ferrous ion chelating ability, results are shown in Figure 2 and EDTA is used as a control. In Figure 2A, all freeze-dried extracts of organic A. formosanus revealed obvious ferrous ion chelating ability. At lower concentrations ( 1 to $2 \mathrm{mg} / \mathrm{mL}$ ), the freeze-dried leaves extract has the best ferrous ion chelating ability than other extracts; the ability can achieve up to $78 \%$ at $2 \mathrm{mg} / \mathrm{mL}$ (Figure 2A). However, at higher concentrations, the ferrous ion chelating ability of freeze-dried leaves extract is reduced with the increasing dosage. At $10 \mathrm{mg} / \mathrm{mL}$, freeze-dried stem extract has the greatest ferrous ion chelating ability higher than $80 \%$ (Figure 2A). Besides, EDTA in all tested concentrations has the highest ferrous ion chelating ability. 


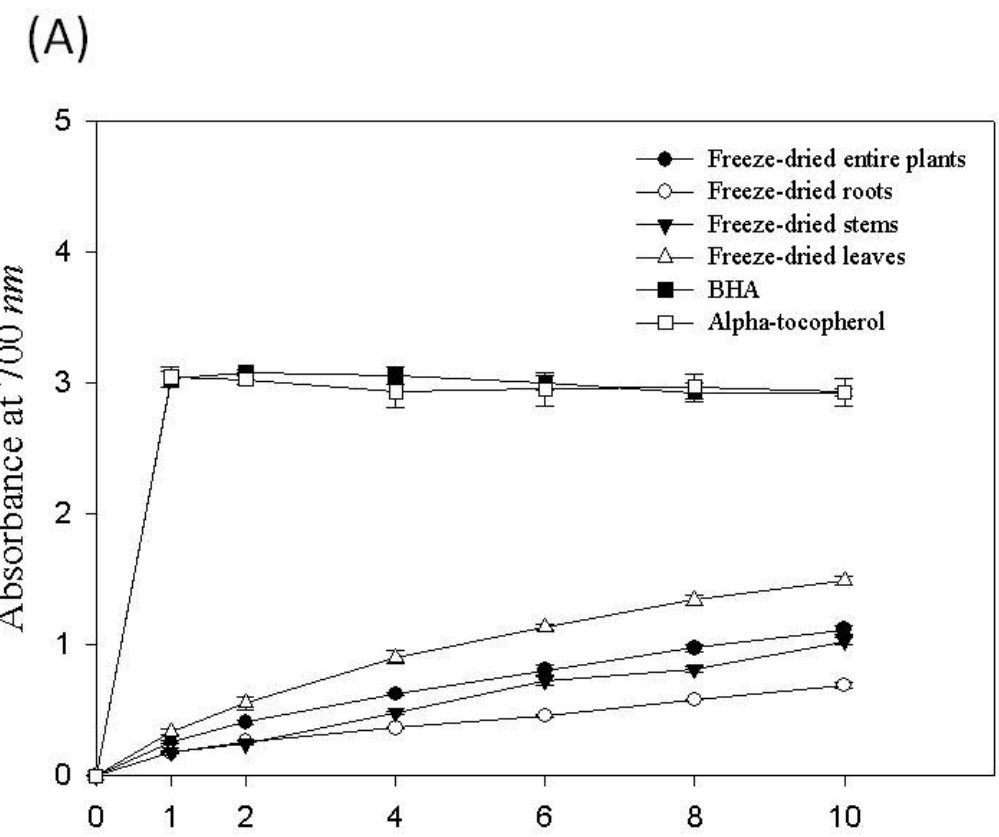

(B)

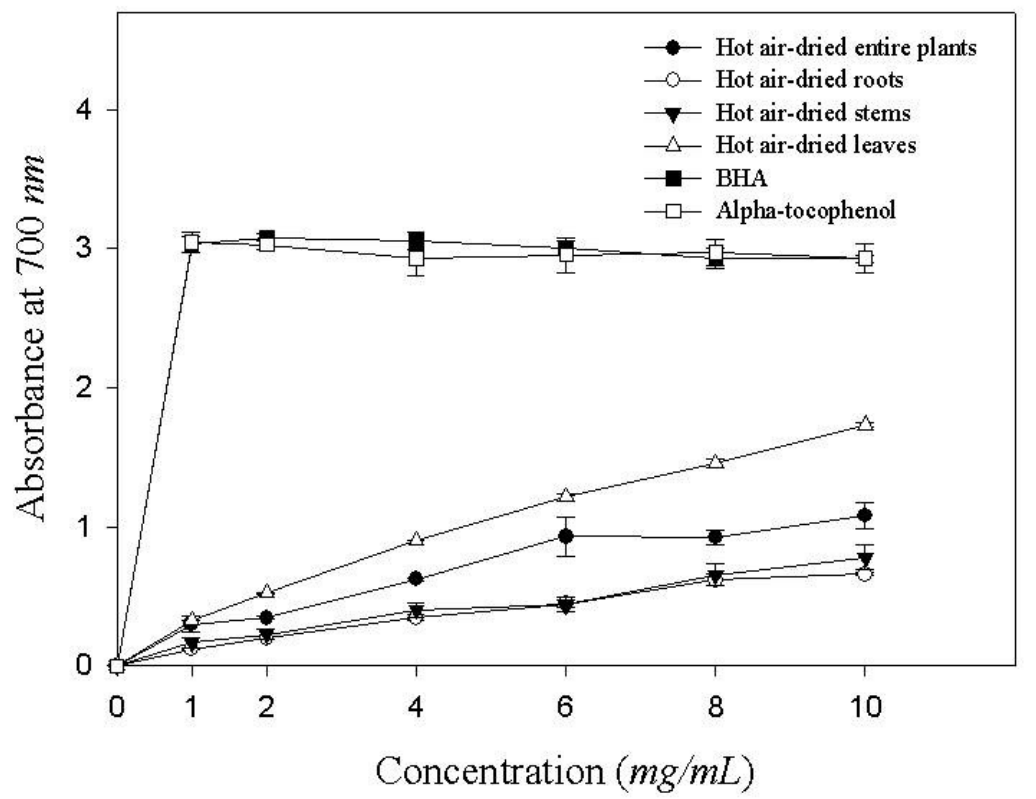

Figure 1. The reducing power of the methanolic extracts of different portions from organic A. formosanus HAYATA, BHA and alpha-tocophenol. (A) Freeze-dried and (B) Hot air-dried. 
(A)

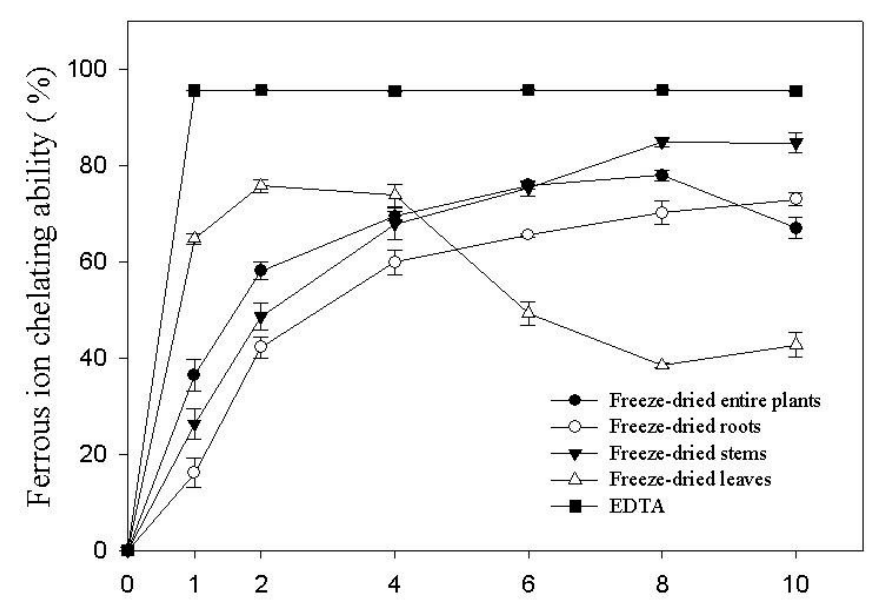

(B)

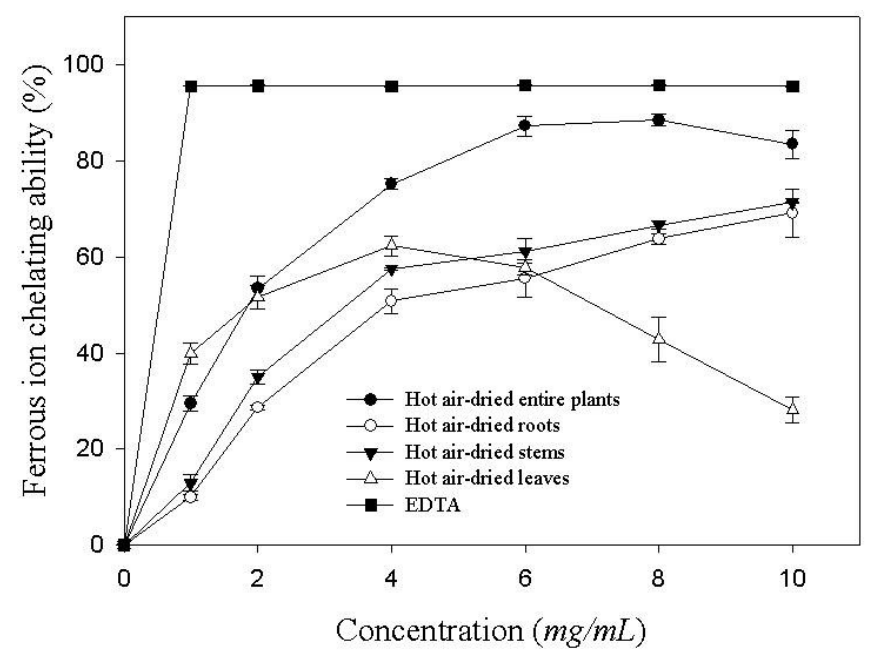

Figure 2. The ferrous ion chelating ability of the methanolic extracts of different portions from organic $A$. formosanus HAYATA and EDTA. (A) Freeze-dried and (B) Hot air-dried.

In the case of the hot air-dried extracts, results are shown in Figure 2B. The extract from hot air-dried entire plants has the most potent ferrous ion chelating ability than other extracts if the concentrations are higher than $4 \mathrm{mg} / \mathrm{mL}$. The ferrous ion chelating ability can be up to $83 \%$ at the concentration of $8 \mathrm{mg} / \mathrm{mL}$ in hot air-dried entire plants extract treated group (Figure 2B). Similar to the results in Figure 2A, the ferrous ion chelating ability of hot air-dried leaves extract increased if between 1 and $4 \mathrm{mg} / \mathrm{mL}$ conditions, but decreased if the concentrations are higher than $4 \mathrm{mg} / \mathrm{mL}$ (Figure 2B). Therefore, the results revealed that the extracts of freeze-dried stem and air-dried entire plants from organic A. formosanus have the greatest ferrous ion chelating abilities at higher concentrations
The DPPH radical scavenging activity of the freeze-dried and hot air-dried methanolic extracts of different portions from organic A. formosanus

In the case of DPPH radical scavenging activity, results are shown in Figure 3; the BHA and $\alpha$-tocopherol are used as control groups. For freezedried extracts of organic A. formosanus, the DPPH radical scavenging activities are all higher than 50\% at the highest concentration $(10 \mathrm{mg} / \mathrm{mL})$. The freeze-dried leaves extract has the greatest DPPH radical scavenging activity than other extracts at the concentration of $10 \mathrm{mg} / \mathrm{mL}$ and higher than both used control compounds (Figure 3A). In additions, the extracts from freeze-dried roots and stems are exhibiting the lowest DPPH radical scavenging activities at all tested concentrations. 


\section{(A)}

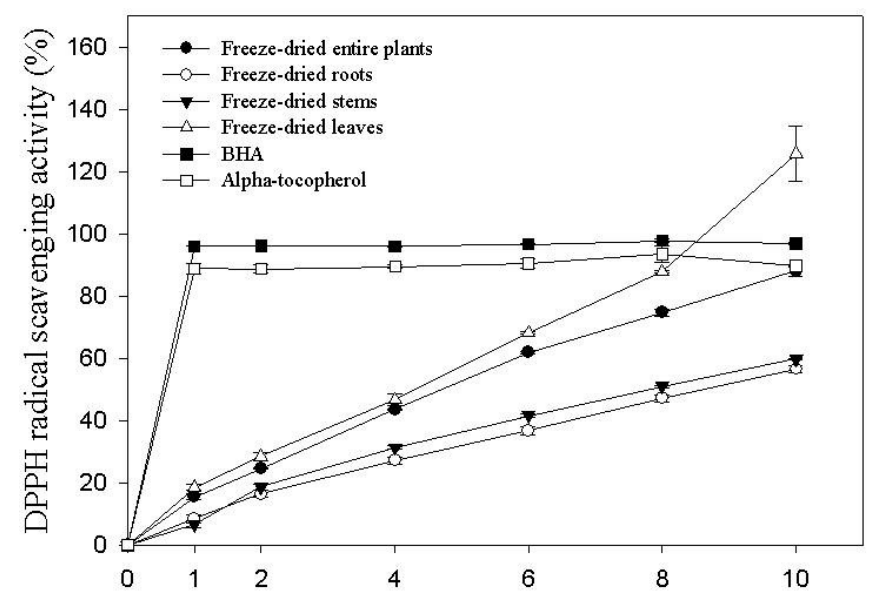

(B)

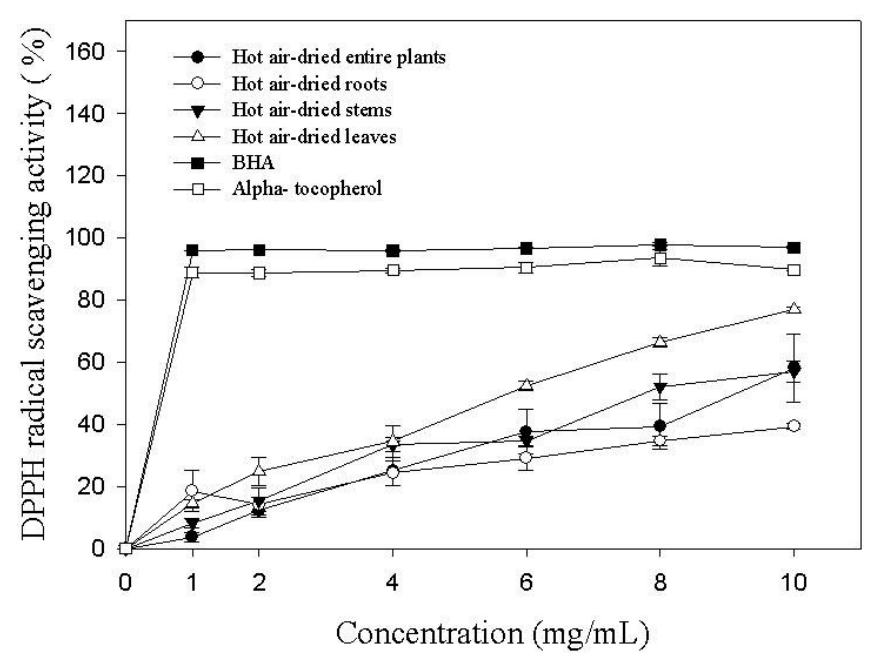

Figure 3. The DPPH radical scavenging activity of the methanolic extracts of different portions from organic A. formosanus HAYATA, BHA and alpha-tocophenol. (A) Freeze-dried and (B) Hot airdried.

For hot air-dried extracts, in Figure 3B, hot air-dried leaves extract has the greatest DPPH radical scavenging activity than other extracts in all used concentrations. Although all hot air-dried extracts have clear DPPH radical scavenging activities, however, results showed that the DPPH radical scavenging activities of hot air-dried extracts are evidently poorer than that of freeze-dried extracts. Therefore, we can suggest that the freezedried extracts of different portions from organic $A$. formosanus have better DPPH radical scavenging activities than the hot air-dried counterpart.

The trolox equivalent antioxidant capacity (TEAC) of the freeze-dried and hot air-dried methanolic extracts of different portions from organic A. formosanus

In the case of the trolox equivalent antioxidant capacity (TEAC) assay, results are shown in Figure 4. The results showed that every freeze-dried organic A. formosanus extracts have clear TEAC values around $2.5 \mathrm{mmol}$ trolox at concentrations from 1 to $10 \mathrm{mg} / \mathrm{mL}$ (Figure 4A). Equally, all hot air-dried organic A. formosanus extracts also exhibited approximately TEAC values of $2.5 \mathrm{mmol}$ trolox in all tested concentrations (Figure 4B). Therefore, the results proposed that two dried processes have no obvious effect on the TEAC of all parts of organic A. formosanus extract (Figure 4). 


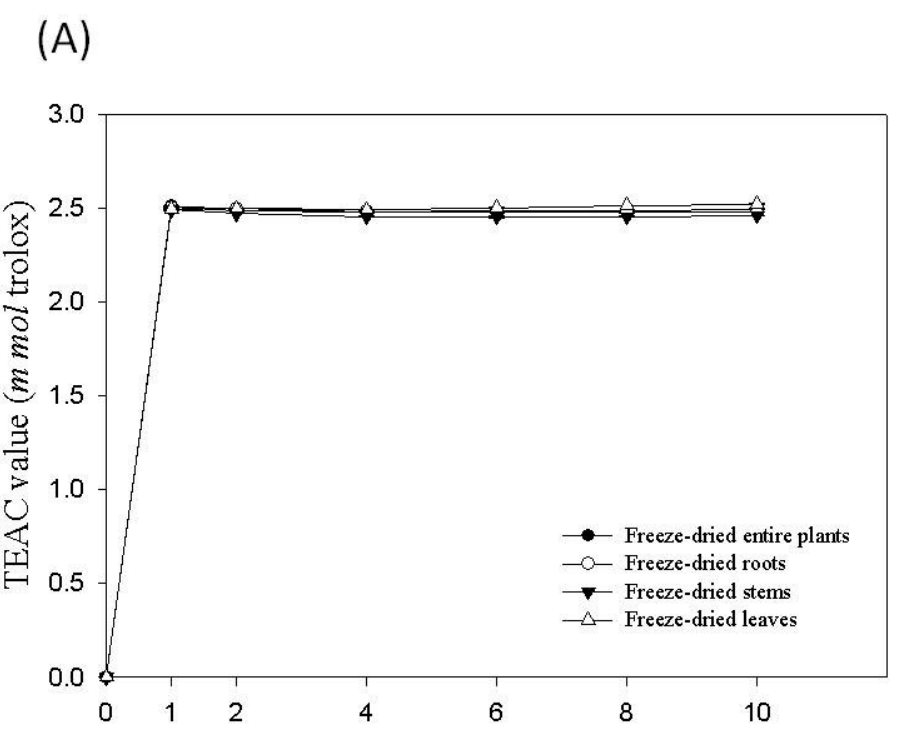

(B)

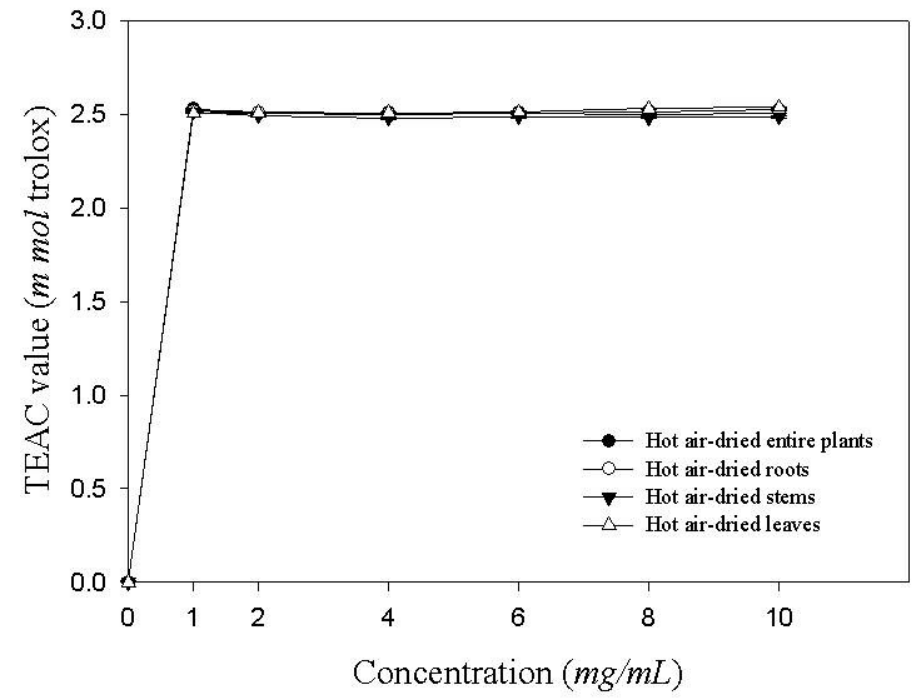

Figure 4. The equivalent trolox antioxidant capacity (TEAC) of the methanolic extracts of different portions from organic A. formosanus HAYATA. (A) Freeze-dried and (B) Hot air-dried.

The contents in active components of freezedried and hot air-dried methanolic extracts of different portions from organic A. formosanus

The contents of active components of freeze-dried organic A. formosanus extracts are shown in Table 1 . On the other hand, the contents of the active components of hot air-dried organic $A$. formosanus extracts are shown in Table 2. The analytical results of the content of active components in different portions from freeze-dried and hot air-dried organic A. formosanus were performed using the Statistic Analysis System (SAS) with one-way ANOVA. Our results showed that hot air-dried process has great effects on the contents of phenols, ascorbic acid and carotenoids in parts of organic A. formosanus. Among them, leaves part has a greatest difference (Table 1 and 2). In contrast, freeze-dried process can obtain abundant flavonoids; the part of leaves has the highest variance (Table 1 and 2). This might be that the two different drying treatments have diverse temperatures in each process. Besides, flavonoids are relatively thermostable than the other antioxidants and active compounds. Therefore, the flavonoids are not as much of different between two processes. 
Table 1. The contents in active components of different portions from freeze-dried A. formosanus HAYATA.

\begin{tabular}{llccc}
\hline Sample & $\begin{array}{l}\text { Phenols } \\
(\mathrm{mg} / \mathrm{g})\end{array}$ & $\begin{array}{l}\text { Flavonoids } \\
(\mathrm{mg} / \mathrm{g})\end{array}$ & $\begin{array}{l}\text { Ascorbic acid } \\
(\mathrm{mg} / \mathrm{g})\end{array}$ & $\begin{array}{l}\text { Carotenoids } \\
(\mathrm{mg} / \mathrm{g})\end{array}$ \\
\hline Entire plants & $14.57 \pm 0.11^{\mathrm{a}}$ & $7.88 \pm 0.04^{\mathrm{b}}$ & $5.39 \pm 0.70^{\mathrm{c}}$ & $10.47 \pm 0.12^{\mathrm{a}}$ \\
Roots & $5.64 \pm 0.06^{\mathrm{d}}$ & $3.99 \pm 0.04^{\mathrm{d}}$ & $0 \pm 0.00^{\mathrm{d}}$ & $9.07 \pm 0.12^{\mathrm{b}}$ \\
Stems & $7.38 \pm 0.06^{\mathrm{c}}$ & $4.25 \pm 0.05^{\mathrm{c}}$ & $8.62 \pm 0.29^{\mathrm{b}}$ & $7.31 \pm 0.11^{\mathrm{c}}$ \\
Leaves & $12.72 \pm 0.15^{\mathrm{b}}$ & $11.87 \pm 0.06^{\mathrm{a}}$ & $13.74 \pm 0.77^{\mathrm{a}}$ & $7.31 \pm 0.11^{\mathrm{c}}$ \\
\hline
\end{tabular}

Each value is expressed as the mean \pm S.D. $(n=3)$; Means with identical letter in the same column are not significantly different at $p<$ 0.05 .

Table 2. The contents in active components of different portions from hot air-dried A. formosanus HAYATA.

\begin{tabular}{lllll}
\hline Sample & $\begin{array}{l}\text { Phenols } \\
(m g / g)\end{array}$ & $\begin{array}{l}\text { Flavonoids } \\
(m g / g)\end{array}$ & $\begin{array}{l}\text { Ascorbic acid } \\
(m g / g)\end{array}$ & $\begin{array}{l}\text { Carotenoids } \\
(m g / g)\end{array}$ \\
\hline Entire plants & $14.40 \pm 0.11^{\mathrm{b}^{*}}$ & $5.89 \pm 0.05^{\mathrm{b}}$ & $11.84 \pm 0.40^{\mathrm{b}}$ & $11.75 \pm 0.20^{\mathrm{b}}$ \\
Roots & $5.98 \pm 0.11^{\mathrm{d}}$ & $3.38 \pm 0.03^{\mathrm{c}}$ & $9.25 \pm 0.22^{\mathrm{c}}$ & $10.70 \pm 0.20^{\mathrm{c}}$ \\
Stems & $11.20 \pm 0.20^{\mathrm{c}}$ & $3.21 \pm 0.04^{\mathrm{d}}$ & $9.73 \pm 0.39^{\mathrm{c}}$ & $11.87 \pm 0.12^{\mathrm{b}}$ \\
Leaves & $21.15 \pm 0.11^{\mathrm{a}}$ & $8.79 \pm 0.04^{\mathrm{a}}$ & $14.29 \pm 0.40^{\mathrm{a}}$ & $12.58 \pm 0.12^{\mathrm{a}}$ \\
\hline
\end{tabular}

Each value is expressed as the mean \pm S.D. $(n=3)$; Means with identical letter in the same column are not significantly different at $p<$ 0.05 .

The correlation coefficients between the content of active components of different portions and the antioxidant properties indices from freezedried and hot air-dried organic $A$. formosanus

The analytical results of the correlations between each sample and the antioxidants were shown in table 3 and 4 . The results are performed through the assessment of a single concentration (10 $\mathrm{mg} / \mathrm{mL}$ ) in all samples with all four-antioxidant activity examined. Our results showed that carotenoids positively correlated with the reducing power and DPPH radical scavenging activity in hot air-dried organic A. formosanus. Moreover, carotenoids positively correlated with the ferrous ion chelating ability in the freeze-dried organic $A$. formosanus. In addition, the contents of phenols and ascorbic acid in all parts of both freeze-dried and hot air-dried organic A. formosanus positively correlated with the reducing power, the DPPH radical scavenging activity and the TEAC.

Table 3. The correlation coefficients between the content of active components of different portions and the antioxidant properties indices from freeze-dried A. formosanus HAYATA.

\begin{tabular}{lllll}
\hline $\begin{array}{l}\text { Antioxidant } \\
\text { properties }\end{array}$ & Phenols & Flavonoids & Ascorbic acid & Carotenoids \\
\hline RP & $0.7355^{* *}$ & $0.9032^{* *}$ & $0.9210^{* *}$ & -0.3752 \\
$(\text { Abs. at } 700 \mathrm{~nm})^{\mathrm{a}}$ & & & & \\
$\begin{array}{l}\text { FICA } \\
(\%)\end{array}$ & $-0.6078^{*}$ & $-0.9308^{* *}$ & -0.5521 & 0.1236 \\
$\begin{array}{l}\text { DRSA } \\
(\%)\end{array}$ & $0.7531^{* *}$ & $0.9721^{* *}$ & $0.7622^{* *}$ & -0.1953 \\
$\begin{array}{l}\text { TEAC } \\
(m \text { mol trolox })\end{array}$ & $0.6618^{*}$ & $0.9365^{* *}$ & 0.5582 & -0.0590 \\
\hline
\end{tabular}

${ }^{a}$ RP: reducing power, FICA: ferrous ion chelating ability, DRSA: DPPH radical; scavenging activity, TEAC: Trolox equivalent antioxidant capacity; *Correlation is significant at $p=0.05$ level; ** Correlation is significant at $p=0.01$ level. 
Table 4. The correlation coefficients between the content of active components of different portions and the antioxidant properties indices from hot air-dried A. formosanus HAYATA.

\begin{tabular}{lllll}
\hline $\begin{array}{l}\text { Antioxidant } \\
\text { properties }\end{array}$ & Phenols & Flavonoids & Ascorbic acid & Carotenoids \\
\hline RP & $0.9566^{* *}$ & $0.9728^{* *}$ & $0.9171^{* *}$ & $0.8152^{* *}$ \\
$(\text { Abs. at } 700 \mathrm{~nm})^{\mathrm{a}}$ & & $-0.7240^{* *}$ & $-0.6688^{*}$ & $-0.5929^{*}$ \\
$\begin{array}{l}\text { FICA } \\
(\%)\end{array}$ & $-0.6745^{*}$ & $0.8442^{* *}$ & $0.8539^{* *}$ & $0.8972^{* *}$ \\
$\begin{array}{l}\text { DRSA } \\
(\%)\end{array}$ & $0.9548^{* *}$ & $0.8318^{* *}$ & $0.7611^{* *}$ & 0.4623 \\
$\begin{array}{l}\text { TEAC } \\
(m \text { mol trolox })\end{array}$ & $0.6818^{*}$ & & \\
\hline
\end{tabular}

${ }^{a}$ RP: reducing power, FICA: ferrous ion chelating ability, DRSA: DPPH radical; scavenging activity, TEAC: Trolox equivalent antioxidant capacity; *Correlation is significant at $p=0.05$ level; ** Correlation is significant at $p=0.01$ level.

\section{DISCUSSION}

In the study, all parts of organic A. formosanus were individually freeze-dried or hot air-dried to remove water. The methanol extracted from the plant extracts were used to analyse the antioxidant properties and active components. These results indicated that antioxidant properties of both the freeze-dried and hot air-dried leaves of organic $A$. formosanus have better performance, including reducing power and $\alpha, \alpha$-diphenyl- $\beta$-picrylhydrazyl (DPPH) radical scavenging activity.

In addition, TEAC assay is a standard method to evaluate the antioxidant activity on the scavenging of radical cation $\mathrm{ABTS}^{+}$. The $\mathrm{ABTS}^{+}$ radical is also one of the compositions used in the method of measuring total antioxidant activity (TAA) for foods, drugs and chemicals (ARNAO et al., 2001). In this study, all freeze-dried and hot airdried organic A. formosanus extracts exhibited the TEAC values of $2.5 \mathrm{mmol}$ trolox in all tested concentrations (Figure 4B). For the reason, we supposed that all the used extraction processes have no effects on the $\mathrm{ABTS}^{+}$radicals scavenging activity of the extracts from every part of organic $A$. formosanus.

In tables 1 and 2, hot air-dried process is better for the contents of total phenols, ascorbic acid and carotenoids. When compared, the variance in leaf part is the most obvious, freeze-dried by lyophilisation can retain plentiful flavonoids; this also noticeable in the results of the leaf part. Therefore, in contrast with the results shown in tables 3 and 4, we can assume that using different processes to extract active components from all parts of organic A. formosanus may affects their antioxidant properties. Some studies have observed that the functional constituents may affect (positively or negatively) the antioxidant activities of plant extract. The phenomenon may be caused by the synergistic effect of these active compounds (LOU et al., 2010; RANJBAR NEDAMANI et al., 2015).

During the drying process of plant materials, drying methods and drying temperatures significantly influenced the extraction efficacy as well as the properties of the extract (WU, 2015). Although the lower extraction temperature may retain the stability of functional constituents, the higher extraction temperature can remove water quickly and also enhance the dissolving of active compounds from plant tissues (GAUR E RAO, 2016). Therefore, the examination for different drying methods in the extraction process is fairly important; this is also conducted in the presented study.

\section{CONCLUSIONs}

The antioxidant properties were improved with increase in sample concentrations of the freeze-dried leaves of organic A. formosanus; it has better reducing power and DPPH radical scavenging activity.

For the trolox equivalent antioxidant capacity, the TEAC values in different parts of organic A. formosanus were close to that of $2.5 \mathrm{mM}$ Trolox.

The contents of phenols and flavonoids showed positive relationships with reducing power, DPPH radical scavenging activity and trolox equivalent antioxidant capacity. Besides, the contents of carotenoids positively correlated with TEAC and the contents of all active components negatively correlated with the ferrous ion chelating ability.

Therefore, freeze-dried leaves of organic $A$. formosanus have better antioxidant properties at proper concentrations. This study may also raise the 
economic values of $A$. formosanus by the organic cultural technique in the future.

\section{ACKNOWLEDGEMENTS}

The authors are grateful for the financial support from the Ministry of Science and
Technology of the Republic of China (Taiwan) awarded to Chih-Chien Lin (MOST 105-2628-B126-002-MY3).

RESUMO: Anoectochilus formosanus HAYATA (Orchidaceae) é uma erva valiosa usada como medicina herbal em Taiwan e outros países asiáticos. A fim de aumentar a eficiência econômica do cultivo orgânico e entender como o processamento afeta as propriedades das plantas, os extratos orgânicos de A. formosanus foram utilizados como material investigativo neste estudo. A planta inteira, as raízes, hastes e folhas de A. formosanus orgânica foram liofilizadas ou secas por ar quente; todas as amostras usaram metanol para a extração. As propriedades antioxidantes e os componentes ativos foram analisados. Os resultados indicaram que as propriedades antioxidantes de ambas as folhas liofilizadas e secas por ar quente da A. formosanus orgânica apresentam melhor desempenho, incluindo o poder redutor e a atividade de eliminação do radical $\alpha, \alpha$-difenil-p-picrilidrazilo (DPPH). Os conteúdos de fenóis e flavonóides mostraram relações positivas com a potência redutora, atividade de eliminação de radicais DPPH e capacidade antioxidante equivalente de trolox. O conteúdo de carotenóides correlacionou-se positivamente com a capacidade antioxidante equivalente de trolox e os conteúdos de todos os componentes ativos foram correlacionados negativamente com a capacidade de quelação de íons ferrosos. Para resumir os resultados, as folhas liofilizadas de A. formosanus orgânica possuem melhores propriedades antioxidantes a uma concentração adequada. Este estudo pode elevar os valores econômicos de A. formosanus pela técnica cultural orgânica.

PALAVRAS-CHAVE: Propriedades antioxidantes. Liofilizado. Seco por ar quente. Anoetochilus formosanus HAYATA orgânica.

\section{REFERENCES}

AINSWORTH, E. A.; GILLESPIE, K. M. Estimation of total phenolic content and other oxidation substrates in plant tissues using Folin-Ciocalteu reagent. Nature Protocols, v. 2, n. 4, p. 875-877, 2007.

http://dx.doi.org/10.1038/nprot.2007.102

ARNAO, M. B.; CANO, A.; ACOSTA, M. The hydrophilic and lipophilic contribution to total antioxidant activity. Food Chemistry, v. 73, n. 2, p. 239-244, 2001. http://dx.doi.org/10.1016/S0308-8146(00)00324-1

ARNAO, M. B.; CANO, A.; HERNANDEZ-RUIZ, J.; GARCIA-CANOVAS, F.; ACOSTA, M. Inhibition by L-ascorbic acid and other antioxidants of the 2.2'-azino-bis(3-ethylbenzthiazoline-6-sulfonic acid) oxidation catalyzed by peroxidase: a new approach for determining total antioxidant status of foods. Analytical Biochemistry, v. 236, n. 2, p. 255-61, 1996. http://dx.doi.org/10.1006/abio.1996.0164

CENCIONI, C.; SPALLOTTA, F.; MARTELLI, F.; VALENTE, S.; MAI, A.; ZEIHER, A. M.; GAETANO, C. Oxidative stress and epigenetic regulation in ageing and age-related diseases. International Journal of Molecular Sciences, v. 14, n. 9, p. 17643-63, 2013. http://dx.doi.org/10.3390/ijms140917643

CHAUHAN, B.; KUMAR, G.; KALAM, N.; ANSARI, S. H. Current concepts and prospects of herbal nutraceutical: A review. Journal of Advanced Pharmaceutical Technology \& Research, v. 4, n. 1, p. 4-8, 2013. https://dx.doi.org/10.4103/2231-4040.107494

CRUZ PADUA, B.; ROSSONI JUNIOR, J. V.; DE BRITO MAGALHAES, C. L.; SEIBERF, J. B.; ARAUJO, C. M.; BIANCO DE SOUZA, G. H.; CHAVES, M. M.; SILVA, M. E.; PEDROSA, M. L.; COSTA, D. C. Baccharis trimera improves the antioxidant defense system and inhibits iNOS and NADPH oxidase expression in a rat model of inflammation. Current Pharmaceutical Biotechnology, v. 14, n. 11, p. 975-84, 2014. http://dx.doi.org/10.2174/1389201014666131226151728 
CZEIZEL, A. E.; DUDAS, I.; VERECZKEY, A.; BANHIDY, F. Folate deficiency and folic acid supplementation: the prevention of neural-tube defects and congenital heart defects. Nutrients, v. 5, n. 11, p. 4760-75, 2013. https://dx.doi.org/10.3390/nu5114760

DECKER, E. A.; WELCH, B. Role of ferritin as a lipid oxidation catalyst in muscle food. Journal of Agricultural and Food Chemistry, v. 38, n. 3, p. 674-677, 1990. http://dx.doi.org/10.1021/jf00093a019

GAUR, T.; RAO, P. B. Antioxidant Potential of the Giant Mushroom, Macrocybe gigantea (Agaricomycetes), from India in Different Drying Methods. International Journal of Medicinal Mushrooms, v. 18, n. 2, p. 13340, 2016. https://dx.doi.org/10.1615/IntJMedMushrooms.v18.i2.40

HAN, Y.; CHEN, J. Z. Oxidative stress induces mitochondrial DNA damage and cytotoxicity through independent mechanisms in human cancer cells. BioMed Research International, v. 2013, p. 825065, 2013. https://dx.doi.org/10.1155/2013/825065

HORWITZ, W.; AOAC INTERNATIONAL. Official methods of analysis of the AOAC. 13. Washington DC: Association of Official Analytical Chemists, 1980. ISBN 9780935584141.

KLEIN, B. P.; PERRY, A. K. Ascorbic Acid and Vitamin A Activity in Selected Vegetables from Different Geographical Areas of the United States. Journal of Food Science, v. 47, n. 3, p. 941-945, 1982. http://dx.doi.org/10.1111/j.1365-2621.1982.tb12750.x

LAI, C. Y.; YANG, L. C.; LIN, W. C. Type II arabinogalactan from Anoectochilus formosanus induced dendritic cell maturation through TLR2 and TLR4. Phytomedicine, v. 22, n. 14, p. 1207-14, 2015. https://dx.doi.org/10.1016/j.phymed.2015.10.010

LIN, J. M.; LIN, C. C.; CHIU, H. F.; YANG, J. J.; LEE, S. G. Evaluation of the anti-inflammatory and liverprotective effects of anoectochilus formosanus, ganoderma lucidum and gynostemma pentaphyllum in rats. American Journal of Chinese Medicine, v. 21, n. 1, p. 59-69, 1993. https://dx.doi.org/10.1142/S0192415X9300008X

LOU, Z.; WANG, H.; LI, J.; CHEN, S.; ZHU, S.; MA, C.; WANG, Z. Antioxidant activity and chemical composition of the fractions from burdock leaves. Journal Food Science, v. 75, n. 5, p. C413-9, 2010. https://dx.doi.org/10.1111/j.1750-3841.2010.01616.x

OYAIZU, M. Studies on Products of Browning Reaction: Antioxidative Activities of Products of Browning Reaction Prepared from Glucosamine. The Japanese Journal of Nutrition and Dietetics, v. 44, n. 6, p. 307315, 1986. http://doi.org/10.5264/eiyogakuzashi.44.307

PENG, C.; WANG, X.; CHEN, J.; JIAO, R.; WANG, L.; LI, Y. M.; ZUO, Y.; LIU, Y.; LEI, L.; MA, K. Y.; HUANG, Y.; CHEN, Z. Y. Biology of Ageing and Role of Dietary Antioxidants. BioMed Research International, v. 2014, p. 831841, 2014. https://dx.doi.org/10.1155/2014/831841

PETCHETTI, L.; FRISHMAN, W. H.; PETRILLO, R.; RAJU, K. Nutriceuticals in cardiovascular disease: psyllium. Cardiology in Review, v. 15, n. 3, p. 116-22, 2007.

https://dx.doi.org/10.1097/01.crd.0000242964.74467.27

QUETTIER-DELEU, C.; GRESSIER, B.; VASSEUR, J.; DINE, T.; BRUNET, C.; LUYCKX, M.; CAZIN, M.; CAZIN, J.-C.; BAILLEUL, F.; TROTIN, F. Phenolic compounds and antioxidant activities of buckwheat (Fagopyrum esculentum Moench) hulls and flour. Journal of Ethnopharmacology, v. 72, n. 1??, p. 35-42, 2000. http://dx.doi.org/10.1016/S0378-8741(00)00196-3 
RANJBAR NEDAMANI, E.; SADEGHI MAHOONAK, A.; GHORBANI, M.; KASHANINEJAD, M. Evaluation of antioxidant interactions in combined extracts of green tea (Camellia sinensis), rosemary (Rosmarinus officinalis) and oak fruit (Quercus branti). Journal of Food Science and Technology, v. 52, n. 7, p. 4565-71, 2015. https://dx.doi.org/10.1007/s13197-014-1497-1

SHIMADA, K.; FUJIKAWA, K.; YAHARA, K.; NAKAMURA, T. Antioxidative properties of xanthan on the autoxidation of soybean oil in cyclodextrin emulsion. Journal of Agricultural and Food Chemistry, v. 40, n. 6, p. 945-948, 1992. http://dx.doi.org/10.1021/jf00018a005

TSENG, C. C.; SHANG, H. F.; WANG, L. F.; SU, B.; HSU, C. C.; KAO, H. Y.; CHENG, K. T. Antitumor and immunostimulating effects of Anoectochilus formosanus Hayata. Phytomedicine, v. 13, n. 5, p. 366-70, 2006. https://dx.doi.org/10.1016/j.phymed.2004.01.016

WANG, S. Y.; KUO, Y. H.; CHANG, H. N.; KANG, P. L.; TSAY, H. S.; LIN, K. F.; YANG, N. S.; SHYUR, L. F. Profiling and characterization antioxidant activities in Anoectochilus formosanus hayata. Journal of Agricultural and Food Chemistry, v. 50, n. 7, p. 1859-65, 2002. http://dx.doi.org/10.1021/jf0113575

WU, Z. Effect of different drying methods on chemical composition and bioactivity of finger citron polysaccharides. International Journal of Biological Macromolecules, v. 76, p. 218-23, 2015. https://dx.doi.org/10.1016/j.ijbiomac.2015.02.043

ZHANG, F. S.; LV, Y. L.; ZHAO, Y.; GUO, S. X. Promoting role of an endophyte on the growth and contents of kinsenosides and flavonoids of Anoectochilus formosanus Hayata, a rare and threatened medicinal Orchidaceae plant. Journal of Zhejiang University SCIENCE B, v. 14, n. 9, p. 785-92, 2013.

https://dx.doi.org/10.1631/jzus.B1300056 